\title{
Predictors of unsuccessful of treatment for fecal incontinence biofeedback for fecal incontinence in female
}

\author{
Sthela M MURAD-REGADAS ${ }^{1,2,3}$, Francisco Sergio P REGADAS ${ }^{1}$, Francisco Sergio P REGADAS FILH0², \\ José Jader de MENDONÇA FILHO', Roberto S ANDRADE FILHO ${ }^{3}$ and Adjra da Silva VILARINHO ${ }^{3}$
}

ABSTRACT - Background - Biofeedback is an effective method of treatment for fecal incontinence but there is controversy regarding factors that may be correlated with its effectiveness. Objective - To evaluate the efficacy of biofeedback in the treatment of fecal incontinence, identifying the predictive factors for unsuccessful treatment. Methods - Consecutive female patients who had fecal incontinence and were treated with a full course of biofeedback were screened. The symptoms were evaluated using Cleveland Clinic incontinence (CCF) score before and six months after the completion of therapy. Patients had a satisfactory clinical response to biofeedback if the CCF score had decreased by more than 50\% at six months (GI) and an unsatisfactory response if the CCF score did not decrease or if the score decreased by $<50 \%$ (GII). The groups were compared with regard to age, score, anal resting and squeeze pressures and sustained squeeze pressure by manometry, history of vaginal delivery, number of vaginal deliveries, menopause, hysterectomy, and previous anorectal surgery. Results - Of 124 women were included, 70 (56\%) in GI and 54 (44\%) in GII. The median CCF score decreased significantly from 10 to $5(P=0.00)$. FI scores were higher in GII. Patients from GII had more previous vaginal deliveries and previous surgeries. The mean sustained squeeze pressure was higher in GI. Patients from GI and GII had similar ages, number of vaginal deliveries, menopause, hysterectomy, anal pressures, and sphincter defects. The median sustained squeeze pressure increased significantly before and after biofeedback in GI. Conclusion - Biofeedback therapy shows effective treatment with 50\% reductions in FI score in half of patients. Factors associated with unsuccessful outcome include FI score $\geq 10$, previous vaginal delivery, previous anorectal and/or colorectal surgery, and reduced mean sustained squeeze pressure.

HEADINGS - Pelvic floor. Fecal incontinence, therapy. Electric stimulation therapy. Treatment outcome.

\section{INTRODUCTION}

Fecal incontinence (FI) can be the result of any anatomic anal sphincter and/or pelvic floor muscle defect(s) associated with neurologic dysfunction. Furthermore, multiple risk factors, such as age, menopause, neurologic conditions such as stroke, dementia, BMI, and diabetic neuropathy have also been implicated ${ }^{(1-3)}$. The symptoms of FI have deleterious effects on the patient and the patient's family and can impair work and social activities, resulting in discomfort, anxiety, and embarrassment ${ }^{(4)}$. Nonsurgical treatment options for FI include therapies such as dietary fiber supplementation, stool-modifying drugs, anal or vaginal plugs, biofeedback combined with pelvic floor muscle training, and rectal irrigation ${ }^{(5-9)}$. Emerging interventions for FI include injection of bulk agents into the anal canal, percutaneous tibial nerve stimulation, and surgical procedures, including radiofrequency anal sphincter remodeling, sacral nerve stimulation (SNS), sphincteroplasty, sphincter replacement, surgical correction of rectal prolapse and, when all other treatments fail, colostomy ${ }^{(10-15)}$.

A series of studies has reported the effectiveness of biofeedback in the treatment of fecal incontinence with improvement of symptoms in between $40 \%$ and $89 \%$ of patients ${ }^{(16-20)}$. However, there is substantial variation in the results of these studies. These variations may be explained by differences in the populations studied, differences in the biofeedback programs used, the small size of the trials, the use of a nonrandomized trial designs, and differences in the severity of fecal incontinence among included patients. This study aimed to evaluate the efficacy of biofeedback in the treatment of FI and to identify the predictive factors for unsuccessful treatment.

\section{METHODS}

\section{Patient selection}

This was a prospective cohort analysis, which included consecutive women patients who had FI and were treated with biofeedback during the period from February 2012 through December 2017 at the Walter Cantídio University Hospital of the Federal University of Ceara. Symptoms were evaluated using the Cleveland Clinic FI score $^{(21)}$ before and six months after the completion of therapy.

Female patients with fecal incontinence symptoms without indication for surgery who were deemed intellectually capable of

Universidade Federal do Ceará, Faculdade de Medicina, Departamento de Cirurgia, Fortaleza, CE, Brasil. ${ }^{2}$ Universidade Federal do Ceará, Hospital das Clínicas, Unidade de Piso Pélvico e Fisiologia Anorretal, Fortaleza, CE, Brasil. ${ }^{3}$ Hospital São Carlos, Departamento de Cirurgia Colorretal, Unidade de Piso Pélvico e Fisiologia Anorretal, CE, Brasil.

Corresponding author: Sthela Murad Regadas. E-mail: smregadas@hospitalsaocarlos.com.br. 
biofeedback treatment and who had undergone a full course of six sessions were included in this study and were divided into two groups according to the percentage of response to treatment: $\mathrm{GI}=$ satisfactory response and GII= unsatisfactory response. Data for age, previous vaginal delivery (VD), number of VDs, previous anorectal and/or colorectal surgery, and hysterectomy were evaluated.

Patients who did not complete a full course of biofeedback therapy or who did not understand or cooperate with the method were excluded. In addition, patients were excluded if they had inflammatory bowel disease, HIV infection, obesity, diabetes, neurologic or psychiatric disorders, symptoms of stress, urge urinary incontinence with an indication for surgery, or fecal incontinence with an indication for surgery. Male patients were excluded due to low numbers.

The clinical protocol was approved by the Research Ethics Committee of the Walter Cantídio University Hospital, and all patients gave written informed consent at database enrollment.

\section{Severity of incontinence}

Fecal incontinence was assessed using the Cleveland Clinic Florida Incontinence Scale ${ }^{(21)}$. The incontinence scale addresses the leakage of gas, liquid and solid stool, need for pads, and lifestyle alteration at varying frequencies, and the extent to which the patient's life is altered.

\section{Anorectal manometry}

Anorectal manometry was performed using a flexible, waterperfused polyethylene catheter and an 8-channel manometer with ProctoMaster software (Dynamed, São Paulo, Brazil) to calculate the length of the anal canal, anal canal pressure at rest, maximum anal squeeze pressure, capacity required to sustain squeeze pressure for 30 seconds, contraction/relaxation of the external anal sphincter and puborectal muscles during straining, and the recto anal inhibitory reflex. Rectal sensitivity (corresponding to the first sensation of rectal filling) and the maximum tolerable volume were measured. The diagnosis of anismus was defined as inappropriate contraction of the pelvic floor or less than $20 \%$ relaxation of basal resting sphincter pressure with adequate propulsive forces during at tempted defecation (repeated at least three times) ${ }^{(22)}$.

\section{Three-dimensional ultrasonography}

All patients underwent 3D anorectal ultrasonography. The examination was performed by a single colorectal surgeon with experience in 3D ultrasonography (S.M.M.R.). A rectal enema was administered 2 hours before the scan. A 3D ultrasound endoprobe was used (Pro-Focus 2052; 12-16 MHz; 3.0-5.2 cm focal distance; B-K Medical, Herlev, Denmark). Images up to $6.0 \mathrm{~cm}$ long were captured along the proximal-distal axis for up to 55 seconds by moving two crystals (axial and longitudinal) on the extremity of the transducer automatically, without moving the probe. The examination involved a series of transaxial microsections up to $0.20 \mathrm{~mm}$ thick, producing a high-resolution digitalized volumetric image. Volume was displayed as a 3D cube image and recorded and analyzed in multiple planes.

The patients were placed in the left lateral position for examination. After digital rectal examination, the endoprobe was introduced as far as the upper anal canal. The ultrasound examination identified the sphincter defect, whether combined external anal sphincter (EAS) and internal anal sphincter (IAS) defects or involving just the EAS. The defect was classified as partial (partially compromised length of the muscle) or total (whole length of the muscle compromised).

\section{Biofeedback therapy}

All patients were recommended dietary habits, fluid management and bowel routines with stools type 3-4 of Bristol scale and underwent a biofeedback training program twice a week, for at least six sessions, up to a maximum of 10 sessions. All treatment was on an outpatient basis. Patients were given detailed information about the objectives of biofeedback therapy and the anatomy and physiology of the pelvic floor. The anorectal manometry system with an 8-lumen catheter and a balloon attached to the tip, as described above, was used for feedback. The catheter was inserted into the anal canal, and the patients viewed the pressure recordings. Patients were instructed to look for changes in pressure, with special attention to the response of the anal sphincter during squeezing, and they were taught how to squeeze and relax the sphincter. The biofeedback program included rapid squeezes and sustained contractions for 10, 20, and 30 seconds. We instructed patients how to maintain the pressure and keep the anal canal closed. Sustained (submaximal) anal sphincter and pelvic floor muscle exercises were routinely included. This was accomplished by trial and error. We also use the filled rectal balloon to train patients to feel the first sensation of rectal filling and instructed patients to squeeze and keep squeezing the sphincter with the filled rectal balloon at 30,60 , and $120 \mathrm{~mL}$. Patients were taught squeezing exercises and sustained contractions for 10, 20, and 30 seconds and were encouraged to practice these maneuvers at home twice per day.

\section{Assessments at follow-up}

Symptoms of FI were evaluated using the Cleveland Clinic FI score before therapy and data 6-month follow-up visit. A patient was regarded as having a satisfactory clinical response to biofeedback if the CCF score had decreased by more than 50\% at 6 months. The response was considered unsatisfactory if the CCF score had not decreased or if the score decrease was $50 \%$ or less.

Manometric measurements were repeated at a follow-up visit six months after the completion of biofeedback therapy.

Patients classified as having a satisfactory response (GI) to therapy were compared with those classified as having an unsatisfactory response (GII) with regard to age, $\mathrm{CCF}$ incontinence score, functional factors (anal resting and squeeze pressures and capacity required to sustain squeeze pressure for 30 seconds on manometry), and anatomic factors in women (history of vaginal delivery, number of vaginal deliveries, menopause, hysterectomy, and previous anorectal surgery such as hemorrhoidectomy, fissurectomy and/or sphincterotomy, fistulotomy, low anterior resection, endo-anal anastomosis).

\section{Statistical analysis}

Pre treatment vs post treatment comparisons were performed using the Wilcoxon signed-ranktest for CCF scores and the paired $t$ test for resting pressure, squeeze pressure, and the capacity required to sustain squeeze pressure for 30 seconds on manometry. Differences between groups were assessed by means of Student's $t$ test for continuous data, the Mann Whitney $U$ test for CCF cores, and the $\mathrm{x}^{2}$ test for categorical data (number of vaginal deliveries, menopause, hysterectomy, and previous anorectal surgery). The level of statistical significance was set at $P<0.05$. Data were analyzed using SPSS software (version 14.0 for Windows; IBMSPSS, Chicago, IL). 


\section{RESULTS}

\section{Patient characteristics}

A total of 124 women were included. The mean age was 64 (SD, 15.8; range, 28-80) years overall.

A total of 90 women $(73 \%)$ had a vaginal delivery, $114(92 \%)$ were post menopausal, $17(14 \%)$ had undergone hysterectomy, and $40(32 \%)$ had undergone previous anorectal surgery. The mean resting pressure was $38.0 \pm 15 \mathrm{mmHg}$, the mean squeeze pressure was $86.0 \pm 36 \mathrm{mmHg}$, and mean sustained squeeze pressure for 30 seconds was $62.0 \pm 26 \mathrm{mmHg}$ by anal manometry. Anorectal 3D ultrasonography identified $29(23 \%)$ patients with external and/or internal anal sphincter defects.

The median pre treatment CCF incontinence score was 10 (range, 3-20).

\section{Satisfactory vs unsatisfactory response}

The median CCF score decreased significantly after therapy from 10 (range, 3-20) to 5 (range, $0-16)(P=0.00)$. The median decrease was $50 \%(0-100 \%)$.

As shown in TABLE 1, of the124female patients, $70(56 \%)$ were classified as having a satisfactory response (decrease in incontinence score $>50 \%$, GI) and $54(44 \%)$ were classified as having an unsatisfactory response (GII). Median CCF score decreased significantly after therapy from 8 (range, $3-20)$ to 3 (range, $0-10)(P=0.01)$ in GI and 12 (range, $4-18)$ to 8 (range, $3-16)(P=0.03)$ in GII. Sixteen $(13 \%)$ patients reported complete continence, all of them in GI.
FI score was higher in GII than in GI ( 12 vs $8, P=0.00)$ and in $33 / 54(61 \%)$ patients in GII the FI score was greater than 10 compared to $19 / 70(27 \%)$ in GI. Patients from GII had more previous vaginal deliveries ( $85 \%$ vs $63 \%, P=0.00)$ and surgeries than GI $(44 \%$ vs $23 \%, P=0.00$ ) (TABLE 1 ). The mean sustained squeeze pressure was higher in GI than in GII before (67 vs $57 \mathrm{mmHg}$, respectively, $P=0.01$ ) and after ( 82 vs $70 \mathrm{mmHg}, P=0.01$ ) BFD (TABLE 2).

Patients from GI and GII had similar ages (mean 64 vs $64 \mathrm{y}$, respectively, $P=0.81$ ), number of vaginal deliveries (median 2 vs $2, P=0.38)$, percent of women in menopause ( $91 \%$ vs $93 \%$, respectively, $P=1.00)$, hysterectomies ( $17 \%$ vs $9 \%$, respectively, $P=0.29)$, mean resting pressure ( 40 vs $36 \mathrm{mmHg}$, respectively, $P=0.13$ ), mean maximum squeeze pressure ( $82 \mathrm{vs} 89 \mathrm{mmHg}, P=0.31$ ) and evidence of sphincter defects (external and/or internal anal sphincter) $(20 \%$ vs $28 \%, P=0.39$ ) (TABLE 1). The median sustained squeeze pressure increased significantly before and after biofeedback in group GI (67 to $82 \mathrm{mmHg}$; $P=0.02$ but was similar in GII ( 57 to $70 \mathrm{mmHg}$; $P=0.05)($ TABLE 2).

\section{DISCUSSION}

This study identified some factors that interfere with the response to biofeedback treatment for FI in a group of female patients and improves our ability to choose appropriate management. Overall, biofeedback improved the symptoms of FI in approximately $50 \%$ of patients. These results are similar to those of several studies in the literature ${ }^{(17-20)}$

TABLE 1. Data for patients who had a satisfactory response (GI) compared to those who had an unsatisfactory response (GII).

\begin{tabular}{|c|c|c|c|}
\hline \multirow{3}{*}{ Data } & \multicolumn{2}{|c|}{ Improvement of CCF incontinence score } & \multirow{3}{*}{$P$} \\
\hline & Satisfactory response $=\mathrm{GI}(>50 \%)$ & Unsatisfactory response $=$ GII $(\leq 50 \%)$ & \\
\hline & 70 females $(56 \%)$ & 54 females $(44 \%)$ & \\
\hline Age mean (SD) & $64( \pm 12)$ & $64( \pm 11)$ & 0.81 \\
\hline CCF incontinence score - after BFD median (range) & $8(3-20)^{a}$ & $12(4-18)^{c}$ & 0.00 \\
\hline CCF incontinence score - before BFD median (range) & $3(0-3)^{b}$ & $8(3-16)^{d}$ & 0.00 \\
\hline Vaginal delivery - median (range) & $2(1-13)$ & $2(1-11)$ & 0.38 \\
\hline Hysterectomy $\mathrm{N}^{\circ}(\%)$ & $12(17)$ & $5(9)$ & 0.29 \\
\hline Anorectal surgery $\mathrm{N}^{\circ}(\%)$ & $16(23)$ & $24(44)$ & 0.00 \\
\hline Sphincter defect & $14(20)$ & $15(28)$ & 0.39 \\
\hline Resting pressure - mean (SD) & $40( \pm 16)$ & $36( \pm 14)$ & 0.13 \\
\hline Squeeze Pressure - mean (SD) & $82( \pm 38)$ & $89( \pm 34)$ & 0.31 \\
\hline
\end{tabular}

CCF: Cleveland Clinic Florida/BFD- biofeedback. The median CCF score had decreased significantly after Biofeedback therapy in GI ${ }^{\text {avs. }}(P=0.00)$ and GII ${ }^{c}$ vs ${ }^{d}(P=0.00)$.

TABLE 2. Sustained squeeze pressure for patients who had a with satisfactory response (GI) and unsatisfactory response (GII) before and after treatment.

\begin{tabular}{|c|c|c|c|}
\hline \multirow[b]{2}{*}{ Anorectal manometry findings } & \multicolumn{2}{|c|}{ Improvement of CCF incontinence score } & \multirow[b]{2}{*}{$P$} \\
\hline & $\begin{array}{c}\text { Satisfactory response }=\mathrm{GI}(>50 \%) \\
70 \text { females }(56 \%)\end{array}$ & $\begin{array}{c}\text { Unsatisfactory response }=\text { GII }(\leq 50 \%) \\
54 \text { females }(44 \%)\end{array}$ & \\
\hline $\begin{array}{l}\text { Before biofeedback } \\
\text { Sustained squeeze } \\
\text { pressure mean (SD) }\end{array}$ & $67( \pm 24)^{\mathrm{a}}$ & $57( \pm 29)^{c}$ & 0.00 \\
\hline $\begin{array}{l}\text { After biofeedback } \\
\text { Sustained squeeze } \\
\text { pressure mean (SD) }\end{array}$ & $82( \pm 29)^{b}$ & $70( \pm 32)^{d}$ & 0.01 \\
\hline
\end{tabular}

The median sustained squeeze pressure increased significantly before and after BFD in GI ${ }^{\text {avs. b }}(P=0.00)$ but not in $\mathrm{GII}^{\mathrm{c}} \mathrm{vs}^{\mathrm{d}}(P=0.05)$. 
In our study, despite of previous recommendations regarding diet, bowel habits to keep the ideal stools, like type 3-4 of Bristol scale and biofeedback training that included rapid squeezes (to improve muscle bulk and reaction times), sustained contractions (to improve strength and endurance), activities to improve perception using a balloon distention following a sustained contraction, similar numbers of sessions, and similar time frames, the responses were not satisfactory for all patients. This may be due to the fact that the samples were heterogeneous in terms of the severity of FI and the presence of risk factors for fecal incontinence. A series of studies has reported data for heterogeneous populations with multiple associated risk factors and different outcomes ${ }^{(18,20,23)}$.

Biofeedback has been frequently recommended as first-line treatment for some types of chronic FI because it has no incidence of adverse effects, is easy to perform, and patients have reported reductions in FI scores ${ }^{(16-20,23,24)}$. However, we should use some criteria to select patients. The most important criteria that was mentioned in this study was sustained squeeze pressure. This was lower in the group with unsatisfactory response and was similar before and after BFD in this group. This parameter is assessed by anal manometry and, in those patients that have no capacity to maintain squeezing, the expected outcome after biofeedback may be limited. This could also discourage the patient from continuing the treatment and cause them to lose confidence in the next treatment option. We consider this to be an important criterion since the biofeedback program in our study included sustained anal sphincter squeezes as well as rapid squeezes, exercises to help patients detect the first sensation of rectal filling using the filled rectal balloon, and exercises for squeezing and maintaining sphincter squeezing with the filled rectal balloon. Therefore, the patients should have improved in their ability to sustain squeeze pressure as assessed by the manometry exam. Furthermore, the patients were encouraged to practice squeezing exercises and sustained contractions for 10,20 , or 30 seconds at home twice per day and were informed about the importance of sustained squeeze pressure. However, a recent randomized study comparing exercise regimens showed that there were no significant differences in objective or subjective measures between two exercise regimens: rapid and sustained exercise group and sustained exercise group ${ }^{(18)}$. Vaginal delivery and the presence of previous anorectal and colorectal surgery were identified as risk factors for FI that changed the result of Biofeedback treatment. The first vaginal delivery is the one most frequently associated with mechanical injury to the anal sphincter and pelvic floor muscles ${ }^{(25,26)}$. On the other hand, the number of vaginal deliveries had no effect on outcomes. The impact of these factors on outcomes in the literature is controversial. Naimy et al. ${ }^{(17)}$ showed that there was no significant improvement in any of the measured scores in those patients with previous vaginal delivery treated with biofeedback and electrostimulation and the presence of vaginal delivery affected the results of treatment. However, Mahony et al. ${ }^{(19)}$ demonstrated significant improvement of FI score and noted that patients benefitted from early treatment started right after delivery (12 weeks after delivery) due to the fact that FI symptoms can probably spontaneously improve up to 6 months after obstetric trauma.

The severity of FI interfered with the results of biofeedback. Patients with higher FI scores had unsatisfactory response. This was demonstrated by our data that showed that in 61\% (33/54) of patients from GII, the FI score was greater than 10 while only $27 \%$ $(19 / 70)$ in GI had an FI score greater than 10, despite the fact that patients in both groups underwent the same uniform biofeedck.

A strength of our study was the number of female patients that underwent uniform biofeedback training. This makes it possible to develop criteria for selection of patients for different FI treatment options since we identified more than one criteria of unsatisfactory response to biofeedback including FI score greater than 10 and poor sustained squeezing pressure.

Studies in the literature include patients with multiple risk factors for FI treated with biofeedback therapy without mentioning the criteria used to select which patients should receive easy-to-implement nonsurgical treatments or more intensive or invasive nonsurgical (Percutaneous tibial posterior anal sphincter tissue bulking injections) or surgical treatments. Studies recommend sacral neuromodulation for incontinent patients with and without sphincter defects in those cases that failed clinical treatment such as diet and biofeedback.

Despite good results and no complications with biofeedback, it is considered a first-line treatment option for patients with FI that have not responded to simple dietary modification, medications, and other supportive measures ${ }^{(27)}$. However, a proportion of patients will not respond to biofeedback and the criteria that were determined in this study may be used to identify these patients and select them for different modalities of treatment. It is preferable for patients to have the specialist choose the appropriate therapy without the need to undergo unnecessary therapy or therapy that is not expected to work. This allows patients to have more confidence in their treatment and they will also not lose time that is better spent starting a therapy with a better chance of success. On the other hand, more studies are necessary to validate the criteria identified in this study.

This study was limited by the short-term follow up of the population. We suggest that future studies should use longer follow-up times and continue reporting the results to confirm satisfactory responses. For this to work, the patients need to be encouraged to continue performing the biofeedback exercises at home. Studies have shown that symptom improvement can be maintained over long-term follow-up periods of 1 to 2 years $^{(28)}$.

\section{CONCLUSION}

Biofeedback therapy provides effective treatment with $50 \%$ reduced FI scores in half of patients. Factors associated with unsuccessful outcomes include FI score $\geq 10$, previous vaginal delivery, previous anorectal and/or colorectal surgery, and reduced mean sustained squeeze pressure. If identified those factors responsible for biofeedback failure, specially reduced mean sustained squeeze pressure, this modality should not to be the first line of treatment. However, there was no correlation between age, number of vaginal deliveries, hysterectomy, sphincter defect and a greater risk of unsuccessful biofeedback treatment.

\section{Authors' contribution}

Murad-Regadas SM, F. Regadas FSP, Andrade Filho RS, Mendonça Filho JJ and Vilarinho AS: conception and design, drafting the article and final approval. Vilarinho AS, Regadas Filho FSP, Mendonça Filho JJ and Murad-Regadas SM: acquisition and analysis of the data, final approval.

\section{Orcid}

Sthela M Murad Regadas. Orcid: 0000-0002-9905-6981.

Francisco Sergio P Regadas. Orcid: 0000-0002-2867-4459.

Francisco Sergio P Regadas Filho. Orcid: 0000-0003-2510-5178.

José Jader de Mendonça Filho. Orcid: 0000-0001-8819-2745.

Roberto S Andrade Filho. Orcid: 0000-0001-8283-7362.

Adjra da Silva Vilarinho. Orcid: 0000-0002-6440-8959. 
Murad-Regadas SM, Regadas FSP, Regadas Filho FSP, Mendonça Filho JJ, Andrade Filho RS, Vilarinho AS. Fatores preditivos de insucesso do biofeedback para tratamento da incontinência fecal em mulheres. Arq Gastroenterol. 2019;56(1):61-5.

RESUMO - Contexto - Biofeedback é um método eficaz de tratamento para a incontinência fecal. No entanto, há controvérsias sobre fatores que podem ser correlacionados com a sua eficácia. Objetivo - Avaliar a eficácia do biofeedback no tratamento da incontinência fecal (IF), identificando os fatores preditivos relacionados ao insucesso do tratamento. Métodos - Consecutivos pacientes do sexo feminino com IF e submetidos a terapia com biofeedback que aceitaram participar do estudo foram incluídos. Os sintomas foram avaliados utilizando o escore de incontinência da Cleveland Clinic-CCF antes e seis meses após termino da terapia. Os pacientes com resposta satisfatória ao biofeedback apresentaram redução no escore de IF $\geq 50 \%$ (GI) e resposta insatisfatória a redução no escore de IF $<50 \%$ (GII) em seis meses. Os grupos foram comparados de acordo com a idade, escore, pressões anais quantificada pela manometria anorretal (repouso, contração e capacidade de sustentação em 30 segundos), parto vaginal prévio, número de partos vaginais, menopausa, histerectomia e cirurgia anorretal e/ou colorretal prévia. Resultados - Total de 124 mulheres incluídas, 70 ( $56 \%$ em GI e $54(44 \%)$ em GII. A mediana do CCF escore reduziu significativamente de 10 para $5(P=0.00)$. FI escore foi mais elevado no GII, assim como foi observado o maior número de mulheres submetidas a partos vaginais e cirurgias prévias. A pressão média de contração foi significante maior no GI. No entanto, idade, número de partos vaginais, menopausa, histerectomia, pressões anais e presença de defeito esfincteriano foram similares nos dois grupos. A pressão média de sustentação mantida por 30 seg aumentou significamente comparando pré com pós biofeedback no GI. Conclusão - O biofeedback é um tratamento eficaz com redução em 50\% no escore de IF em mais da metade dos pacientes. Os fatores associados ao insucesso do tratamento incluem o escore de IF $\geq 10$, parto vaginal prévio, cirurgia anorretal prévia e pressão média de sustentação reduzida.

DESCRITORES - Assoalho pélvico. Incontinência fecal, terapia. Terapia por estimulação elétrica. Resultado do tratamento.

\section{REFERENCES}

1. Rao SS; American College of Gastroenterology Practice Parameters Committee. Diagnosis and management of fecal incontinence. American College of Gastroenterology Practice Parameters Committee. Am J Gastroenterol. 2004;99:1585-604.

2. Bharucha AE, Fletcher JG, Melton LJ 3rd, Zinsmeister AR. Obstetric trauma, pelvic floor injury and fecal incontinence: a population-based case-control study. Am J Gastroenterol. 2012;107:902-11.

3. Ownsend MK, Matthews CA, Whitehead WE, Grodstein F. Risk factors for fecal incontinence in older women. Am J Gastroenterol. 2013;108:113-9.

4. Bharucha AE, Zinsmeister AR, Locke GR, Schleck C, McKeon K, Melton LJ. Symptoms and quality of life in community women with fecal incontinence. Clin Gastroenterol Hepatol. 2006;4:1004-9.

5. Omar MI, Alexander CE. Drug treatment for faecal incontinence in adults Cochrane Database Syst Rev. 2013;6:CD002116.

6. Cazemier M, Felt-Bersma RJ, Mulder CJ. Anal plugs and retrograde colonic irrigation are helpful in fecal incontinence or constipation. World J Gastroenterol. 2007;13:3101-5.

7. Deutekom M, Dobben AC. Plugs for containing faecal incontinence. Cochrane Database Syst Rev. 2012;4:CD005086.

8. Richter HE, Matthews CA, Muir T, Takase-Sanchez MM, Hale DS, Van Drie D, Varma MG. Obstet Gynecol. 2015; 125:540-7.

9. Norton C, Cody JD. Biofeedback and/or sphincter exercises for the treatment of faecal incontinence in adults. Cochrane Database Syst Rev. 2012;7:CD002111.

10. Maeda Y, Laurberg S, Norton C. Perianal injectable bulking agents as treatment for faecal incontinence in adults. Cochrane Database Syst Rev. 2013;2:CD007959.

11. Govaert B, Pares D, Delgado-Aros S, La Torre F, Van Gemert WG, Baeten CG. A prospective multicentre study to investigate percutaneous tibial nerve stimulation for the treatment of faecal incontinence. Colorectal Dis. 2010;12:1236-41.

12. Ruiz D, Pinto RA, Hull TL, Efron JE, Wexner SD. Does the radiofrequency procedure for fecal incontinence improve quality of life and incontinence at 1-year follow-up? Dis Colon Rectum. 2010;53:1041-6.

13. Hull T Giese C, Wexner SD, Mellgren A, Devroede G, Madoff RD, et al. Longterm durability of sacral nerve stimulation therapy for chronic fecal incontinence. Dis Colon Rectum. 2013;56:234-45.

14. Forte ML, Andrade KE, Lowry AC, Butler M, Bliss DZ, Kane RL Systematic Review of Surgical Treatments for Fecal Incontinence. Dis Colon Rectum. 2016;59:443-69.

15. Tan EK, Vaizey C, Cornish J, Darzi A, Tekkis PP. Surgical strategies for faecal incontinence-a decision analysis between dynamic graciloplasty, artificial bowel sphincter and end stoma. Colorectal Dis. 2008;10:577-86.
16. Martínez-Puente M del C, Pascual-Montero JA, García-Olmo D. Customized biofeedback therapy improves results in fecal incontinence. Int J Colorectal Dis. 2004; 19:210-14

17. Naimy N, Lindam AT, Bakka A, Faerden AE, Wiik P, Carlsen E, et al. Biofeedback vs electrostimulation in the treatment of postdelivery anal incontinence: a randomized clinical trial. Dis Colon Rectum. 2007;50:2040-6.

18. Bartlett L, Sloots K, Nowak M, Ho YH. Biofeedback for fecal incontinence: a randomized study comparing exercise regimens. Dis Colon Rectum. 2011;54: 846-56.

19. Mahony RT, Malone PA, Nalty J, Behan M, O'connell PR, O'herlihy C. Randomized clinical trial of intra-anal electromyographic biofeedback physiotherapy with intra-anal electromyographic biofeedback augmented with electrical stimulation of the anal sphincter in the early treatment of postpartum fecal incontinence. Am J Obstet Gynecol. 2004;191:885-90.

20. Young CJ, Zahid A, Koh CE, Young JM, Byrne CM, Solomon MJ. A randomized controlled trial of four different regimes of biofeedback programme in the treatment of faecal incontinence. Colorectal Dis. 2018;20:312-20.

21. Jorge JM, Wexner SD. Etiology and management of fecal incontinence. Dis Colon Rectum. 1993;36:77-97.

22. Bharucha AE, Wald A, Enck P, Rao S. Functional anorectal disorders. Gastroenterology. 2006;130:1510-8.

23. Norton C, Kamm MA. Anal sphincter biofeedback and pelvic floor exercises for faecal incontinence in adults: a systematic review. Aliment Pharmacol Ther. 2001; $15: 1147-54$.

24. Heymen S, Scarlett Y, Jones K, Ringel Y, Drossman D, Whitehead WE. Randomized controlled trial shows biofeedback to be superior to pelvic floor exercises for fecal incontinence. Dis Colon Rectum. 2009;52:1730-7.

25. Sultan AH, Bartram CI, Hudson CN, Kamm MA, Thomas JM. Anal sphincter disruption during vaginal delivery. N Engl J Med. 1993;329:1905-11.

26. Damon H, Henry L, Bretones S, Mellier G, Minaire Y, Mion F. Postdelivery anal function in primiparous females: ultrasound and manometric study. Dis Colon Rectum. 2000;43:472-7.

27. Paquette IM, Varma MG, Kaiser AM, Steele SR, Rafferty JF. The American Society of Colon and Rectal Surgeons'Clinical Practice Guideline for the Treatment of Fecal Incontinence. Dis Colon Rectum. 2015;58:623-36.

28. Enck P, Däublin G, Lübke HJ, Strohmeyer G. Long-Term Efficacy of Biofeedback Training for Fecal Incontinence. Dis Colon Rectum. 1994;37:997-1001. 